\title{
Article \\ Comparison of Juvenile, Drought Tolerant Black Locust (Robinia pseudoacacia L.) Clones with Regard to Plant Physiology and Growth Characteristics in Eastern Hungary: Early Evaluation
}

\author{
Tamás Ábri ${ }^{1,2}$, Zsolt Keserú ${ }^{1, *}$, Attila Borovics ${ }^{3}$, Károly Rédei ${ }^{4}$ and József Csajbók ${ }^{2}$ (D) \\ 1 Department of Plantation Forestry, Forest Research Institute, University of Sopron, Farkassziget 3, \\ H-4150 Püspökladány, Hungary; abri.tamas@uni-sopron.hu \\ 2 Faculty of Agricultural and Food Sciences and Environmental Management, Institute of Crop Sciences, \\ University of Debrecen, Böszörményi Str. 138, H-4032 Debrecen, Hungary; csj@agr.unideb.hu \\ 3 Department of Forest Tree Breeding, Forest Research Institute, University of Sopron, Várkerület Str. 30/A, \\ H-9600 Sárvár, Hungary; borovics.attila@uni-sopron.hu \\ 4 Faculty of Agricultural and Food Sciences and Environmental Management, Institute of Animal Science, \\ Biotechnology and Nature, University of Debrecen, Böszörményi Str. 138, H-4032 Debrecen, Hungary; \\ redei.karoly@gmail.com \\ * Correspondence: keseru.zsolt@uni-sopron.com; Tel.: +36-54-451-169
}

check for updates

Citation: Ábri, T.; Keserû, Z.; Borovics, A.; Rédei, K.; Csajbók, J. Comparison of Juvenile, Drought Tolerant Black Locust (Robinia pseudoacacia L.) Clones with Regard to Plant Physiology and Growth Characteristics in Eastern Hungary: Early Evaluation. Forests 2022, 13, 292. https://doi.org/10.3390/ f13020292

Academic Editor: Ilona Mészáros

Received: 13 January 2022

Accepted: 8 February 2022

Published: 11 February 2022

Publisher's Note: MDPI stays neutral with regard to jurisdictional claims in published maps and institutional affiliations.

Copyright: (C) 2022 by the authors. Licensee MDPI, Basel, Switzerland. This article is an open access article distributed under the terms and conditions of the Creative Commons Attribution (CC BY) license (https:// creativecommons.org/licenses/by/ $4.0 /)$.

\begin{abstract}
Background: The aim of our study is to present the results of initial growth and plant physiology studies of newly selected, vegetative propagated black locust clones, with a view to assess their suitability for the establishment of fast growing tree plantations for the production of high quality timber in marginal (semi-arid) sites. (2) Methods: In the spring (May) and autumn (November) of 2021, full inventories were carried out in the black locust industrial tree plantation. The Normalized Difference Vegetation Index (NDVI) values were observed monthly from May to September 2021. For measuring the assimilation parameters the net assimilation, transpiration, stomatal conductance, intercellular $\mathrm{CO}_{2}$ concentration, and other physiological parameters were recorded. (3) Results: Robinia pseudoacacia 'NK2' clone showed the highest assimilation rate and it produced the most height increment in the growing season, from May 2021 to November 2021. The discriminant analysis classified successfully the black locust clones, $86.7 \%$ of original grouped cases were correctly classified. (4) Conclusions: The study of industrial tree plantations is of great practical importance. As black locust can tolerate even marginal site conditions, the lack of timber can be reduced in the future by establishing black locust industrial tree plantations. To be able to produce good quality industrial wood on the plantations, it is essential to study the phytophysiological properties of the trees (biomass production, vegetation activity of plants, chlorophyll content, photosynthetic activity) in addition to the traditional stand full inventories.
\end{abstract}

Keywords: black locust clones; drought tolerant; plant physiology; growth characteristics; Hungary

\section{Introduction}

Black locust is one of the most commonly planted exotic tree species all around the world [1,2]. However, it is indigenous to North America (southern Appalachians), it has no important role in the forest management of the USA [3]. It is widespread and has economic importance in Central Europe (e.g., Germany, Poland, Romania, and Hungary) and East Asia (China and South Korea) [2,4-11]. It is a drought-tolerant tree species, that plays a significant role in mitigating the negative effects of climate change [1,12-14]. Drought stress reduces the morphological (plant growth, height, and stem diameter) and physiological traits (leaf water potential and sap movement, net assimilation rate and stomatal conductance), and also the hydraulic properties in the plants [15]. Besides the production 
of classical wood products (poles, props, fuelwood), black locust is used particularly for erosion control [2,16], reforestation of denuded mountains [17], and reclaiming forming mine sites [18-21]. It is also considered important for short rotation energy crops [6,22,23]. Last, but not least, its role in apiculture is also relevant [24-27].

It was introduced in Europe in the 17th and to Hungary in the early 18th century [28-30]. Its rapid growth, widescale tolerance, hard, durable wood, and versatile uses (e.g., energy, beekeeping, industry, soil protection) have led to its rapid spread [24,26]. It is one of the best honey-producing plants. One hectare of black locust stand can produce more than $1500 \mathrm{~kg}$ of high-quality honey [31]. It thrives on marginal sites but grows best on sites with good fertility (deep productive layer, rich in nutrients), adequate water balance, loose, less acidic, sandy, sandy loam soils with near neutral chemistry [32-34]. Today, in Hungary, black locust grows approximately $24 \%$ of the more than 2 million ha of tree cover [35]. Currently, it is the most widely cultivated tree species in Hungary.

However, black locust varies from specimen to specimen, has numerous disadvantages (curved trunk, forking, low industrial wood yield, susceptibility to frost, etc.) in the context of growing technology [24,26]. Therefore, in the early 1960s, research work was initiated at the Hungarian Forest Research Institute to improve the stem quality and increase the yield of black locust $[22,24]$. In the last decades, several programs have been launched, which have resulted in numerous state-approved cultivars and candidate cultivars [24,36-42].

In parallel with the above, there has been an increasing international interest in the Research and Development and Innovation (R \& D \& I) results and practical experiences that can help the improvement of Hungarian black locust cultivation. Several countries have sent researchers and apprentices to Hungary to study black locust growing technology. A large number of studies and scientific articles have been published at an international level [22,24,25,37-41,43-45], and in the late 1980s and early 1990s, the export of propagating material of some black locust cultivars and candidate cultivars was initiated.

Currently, a joint project of the University of Sopron and Napkori Erdőgazdák Zrt. is studying and testing the growing technology of black locust in industrial tree plantations and new high-performance black locust clones with high yields of industrial timber (min. 50\%) near Napkor.

Apart from Hungary, black locust research programs are being carried out in several countries of the world (USA, Germany, Poland, Greece, Bulgaria, India, China, South Korea) and successes have been achieved in black locust breeding and growing technology [6,7,20,26,46-62].

The aim of this manuscript is to present the results of initial growth and plant physiology studies of newly selected, vegetative propagated black locust clones, aiming to assess their suitability for the establishment of fast growing tree plantations for the production of high quality timber in marginal (semi-arid) sites. Our Hypothesis 1 assumes that there are significant differences between the growth (height and diameter at the base) and the plant physiology traits (photosynthetic activity, assimilation rate, transpiration, and water use efficiency) of the investigated clones. Furthermore, Hypothesis 2 assumes that the clones can be separated based on the measured data.

\section{Materials and Methods}

In this paper, a black locust industrial tree plantation is presented, where two black locust clones selected in Püspökladány ('PL251', 'PL040') and two in Napkor ('NK1', 'NK2') and one state-approved cultivar ('Ülloii') are tested and compared.

In the course of our study, the usual dendrometric parameters (measurement of diameter at the base and height) were supplemented by measurements to examine the plant physiology characteristics of the clones-Normalized Difference Vegetation Index (NDVI), photosynthetic activity. NDVI is a measure on a scale of 0 to 1 (the closer to 1 , the healthier the plant), which determines how much of the photosynthetically useful radiation is absorbed or reflected by the plant's leaf. The more absorbed, the more active the vegetation is, which is related to the chlorophyll content of the leaves. It is an excellent 
method for monitoring the nitrogen supply of plants (and thus the $\mathrm{N}$ supply capacity of the site) and their vitality [63].

\subsection{Experiment Set Up}

The industrial tree plantation $\left(47^{\circ} 55^{\prime} 13^{\prime \prime} \mathrm{N}, 21^{\circ} 50^{\prime} 45^{\prime \prime} \mathrm{E}\right)$ near Napkor, which is also a clone comparison trial, was established in 2020. The 2.66 ha site is located in the northeastern part of the Hungarian Great Plain, in the middle of the region called Nyírség, where the average annual temperature is $10.4{ }^{\circ} \mathrm{C}$ and the average annual precipitation is $527.4 \mathrm{~mm}$ [64], based on meteorological data for the last 35 years (1985-2020).

Based on the results of our soil analysis, the soil of the site is humus sandy soil (Arenosol, [65]) the humus content is low $(\mathrm{Hu} \%=0.21-0.36)$, acidic $\left(\mathrm{pH}_{\mathrm{KCl}} 5.17-5.34\right)$. In the experiment, 4 black locust clones and the 'Üllöi' state-approved cultivar were tested in 3 different planting spaces $(2.5 \times 2.5 \mathrm{~m} ; 3 \times 3 \mathrm{~m} ; 4 \times 4 \mathrm{~m})$. In our study, we present the results of the comparison of clones in the $3 \times 3 \mathrm{~m}$ planting space.

The vegetatively propagated seedlings were planted in spring 2020. After planting, the necessary maintenance (cultivation of row and spacing, pruning) was carried out.

\subsection{Field Measurements}

In the spring (May) and autumn (November) of 2021, full inventories were carried out in the plantation. The diameter was measured at the base $(\mathrm{mm})$ with a Powerfix digital caliper and height $(\mathrm{cm})$ with a height measuring ruler. We measured 137-146 trees from clone 'PL251', 157-174 from clone 'NK1', 124-126 from 'PL040', 50-97 from 'NK2' and 81-84 from 'Ülloi' during full inventories. Furthermore, the height of 30-30 selected trees of average growth per clone was measured every two months from May 2021 to November 2021.

The Normalized Difference Vegetation Index (NDVI) values were observed monthly from May to September 2021, based on the absorption and reflection of near infrared and visible red light [63]. Trimble (Sunnyvale, California, USA) GreenSeeker handheld crop sensor was used in the NDVI measurements. This sensor utilizes active illumination with light-emitting diodes (LED) at two wavelengths $656 \mathrm{~nm}$ and $774 \mathrm{~nm}$. Ten measurements per clone were completed.

LI-6800 (LI-COR, Lincoln, NE, USA) portable photosynthesis system was used in the assimilation parameters measurements. The instrument recorded the net assimilation, transpiration, stomatal conductance, intercellular $\mathrm{CO}_{2}$ concentration, and other physiological parameters [66]. The light was controlled in the sample chamber, we used $1500 \mu \mathrm{mol}$ photon $\mathrm{m}^{-2} \mathrm{~s}^{-1}$ PAR, with $90 \%$ red $(625 \mathrm{~nm})$ and $10 \%$ blue $(475 \mathrm{~nm})$ light. For the light response curve, we used decreasing photosynthetic photon flux density (PPFD) in 8 steps $\left(1500,1200,900,600,300,150,50,0 \mu \mathrm{mol} \mathrm{m}^{-2} \mathrm{~s}^{-1}\right)$.

The Li-6800-01A multiphase flash fluorometer head was used as a light source, the aperture was $2 \mathrm{~cm}^{2}$. The $\mathrm{CO}_{2}$ concentration was controlled in the chamber: $400 \mu \mathrm{mol} \mathrm{mol}{ }^{-1}$ using injector and carbon dioxide patrons. Light-adapted leaves were measured, six times per leaf on three plants per plot. Readings were logged when the measured parameters stabilized but after a minimum of $120 \mathrm{~s}$.

To calculate water use efficiency data measured on the leaves were used applying the formula proposed by Tanner and Sinclair [67], (Equation (1)).

$$
\text { WUE }=\left(\text { Ass }^{*} 44\right) /(E m m * 18)
$$

WUE: water use efficiency $\left(\mathrm{kg} \mathrm{m}^{-3}\right)$

Emm: transpirated $\mathrm{H}_{2} \mathrm{O}\left(\mathrm{mmol} \mathrm{m}^{2} \mathrm{~s}^{-1}\right)$

Ass: assimilated $\mathrm{CO}_{2}\left(\mu \mathrm{mol} \mathrm{m} 2 \mathrm{~s}^{-1}\right)$. 


\subsection{Evapotranspiration and VPD Calculations}

The FAO Penman-Monteith method was used in the calculation of potential evapotranspiration (PET) with climatic data collected at the experiment site [68] (Equation (2)).

$$
P E T=\frac{0.408 \Delta\left(R_{n}-G\right)+\gamma \frac{900}{T+273} u_{2}\left(e_{s}-e_{a}\right)}{\Delta+\gamma\left(1+0.34 u_{2}\right)}
$$

PET: potential evapotranspiration $\left(\mathrm{mm} \mathrm{day}^{-1}\right)$,

$R_{n}$ : net radiation at the crop surface $\left(\mathrm{MJ} \mathrm{m}^{-2}\right.$ day $\left.^{-1}\right)$,

$G$ : soil heat flux density ( $\mathrm{MJ} \mathrm{m} \mathrm{m}^{-2}$ day $\left.^{-1}\right)$,

T: mean daily air temperature at $2 \mathrm{~m}$ height $\left({ }^{\circ} \mathrm{C}\right)$,

$u_{2}$ : wind speed at $2 \mathrm{~m}$ height $\left(\mathrm{m} \mathrm{s}^{-1}\right)$,

$e_{s}$ : saturation vapour pressure $(\mathrm{kPa})$,

$e_{a}:$ actual vapour pressure $(\mathrm{kPa})$,

$\Delta$ : slope vapour pressure curve $\left(\mathrm{kPa}^{\circ} \mathrm{C}^{-1}\right)$,

$\gamma$ : psychrometric constant $\left(\mathrm{kPa}^{\circ} \mathrm{C}^{-1}\right)$

Actual evapotranspiration (AET) was estimated using the formula of [69]. The method uses the PET, the soil moisture data and the crop coefficient values (Equations (3) and (4)).

$$
A E T=\frac{w+b}{1+b} * w * P E T
$$

AET: actual evapotranspiration $\left(\mathrm{mm} \mathrm{day}^{-1}\right)$,

$w$ : relative soil moisture content in the $0-100 \mathrm{~cm}$ layer $(\mathrm{mm})$

$b$ : crop coefficient factor of trees

PET: potential evapotranspiration $\left(\mathrm{mm} \mathrm{day}^{-1}\right)$

$$
w=\frac{W_{a}-W P}{W_{c-} W P}
$$

$w$ : relative soil moisture content in the $0-100 \mathrm{~cm}$ layer $(\mathrm{mm})$

$W P$ : permanent wilting point of the soil $(\mathrm{mm})$

$W_{c}$ : field capacity of the soil $(\mathrm{mm})$

Vapor pressure deficit (VPD) in kilopascals was calculated from saturated vapor pressure $\left(V P_{\text {sat }}\right)$ and actual vapor pressure $\left(V P_{\text {air }}\right)$ :

$$
\begin{gathered}
V P_{\text {sat }}=\frac{610.7 * 10^{\frac{7.45 * T}{237.3+T}}}{1000} \\
V P_{\text {air }}=\frac{610.7 * 10^{\frac{7.45 * T}{237.3+T}}}{1000} * \frac{R H}{100}
\end{gathered}
$$

$V P_{\text {sat }}$ : saturated vapor pressure of the $\operatorname{air}(\mathrm{kPa})$,

$T$ : air temperature $\left({ }^{\circ} \mathrm{C}\right)$

$V P_{\text {air }}$ : actual vapor pressure of the air $(\mathrm{kPa})$

$$
\mathrm{VPD}=\mathrm{VP}_{\text {sat }}-\mathrm{VP}_{\text {air }}
$$

\subsection{Statistical Data Analysis}

The data were statistically analysed with IBM SPSS 25.0 statistical software package and MS Excel 2016. The results of the stand survey (height, diameter at the base) and NDVI measurements were analysed with one-way analysis of variance (ANOVA), and the significance of differences between means was assessed with the LSD test $(p=0.05)$. Natural logarithmic regression functions were calculated in the analysis of assimilation rate light response curves. Discriminant analysis was used on standardized values to classify and test the group membership of the clones. Pearson correlation analysis (2-tailed) was 
run to reveal the linear relationships among the parameters. The standard error $( \pm)$ and significance was presented on the figures and tables where it was relevant.

\section{Results}

\subsection{Evaluation of Weather Conditions of the Black Locust Experiment Site}

It seems to be due mostly to the climate change, the annual average temperature in 2021 (from January 2021 to December 2021 ) was $0.3^{\circ} \mathrm{C}$ higher $\left(10.7^{\circ} \mathrm{C}\right)$ than the $35-$ year (1985-2020) average. Furthermore, in 2021, the total annual precipitation (524.7 mm) was below the 35-year average. The precipitation in the period from May 2021 to November 2021 (between our full investigations) was $291.6 \mathrm{~mm}$, during main growing-main water consumption (from May 2021 to July 2021) was $156.3 \mathrm{~mm}$ and in the period of critical months (July and August) was 127.3 mm [64] (Figure 1). Two months, June and October were very dry, the rainfall was only 7.5 and $0.8 \mathrm{~mm}$ respectively. The PET and AET, their ratio, and the VPD were calculated characterizing the water supply of black locust (Figure 2). The AET/PET ratio data supported that there was a very dry growing season in 2021 for the black locust. From 15 March to 31 October, the ratio was only 39\% on average. In the two very important month, for the growth of the black locust, May and June, the average ratio was only 35\%. The AET was only 24 and $25 \%$ of the PET values in the 3rd decade of June and the first decade of July, respectively. These low values show that the evapotranspiration was limited by the very low available moisture content in the root zone in the soil.

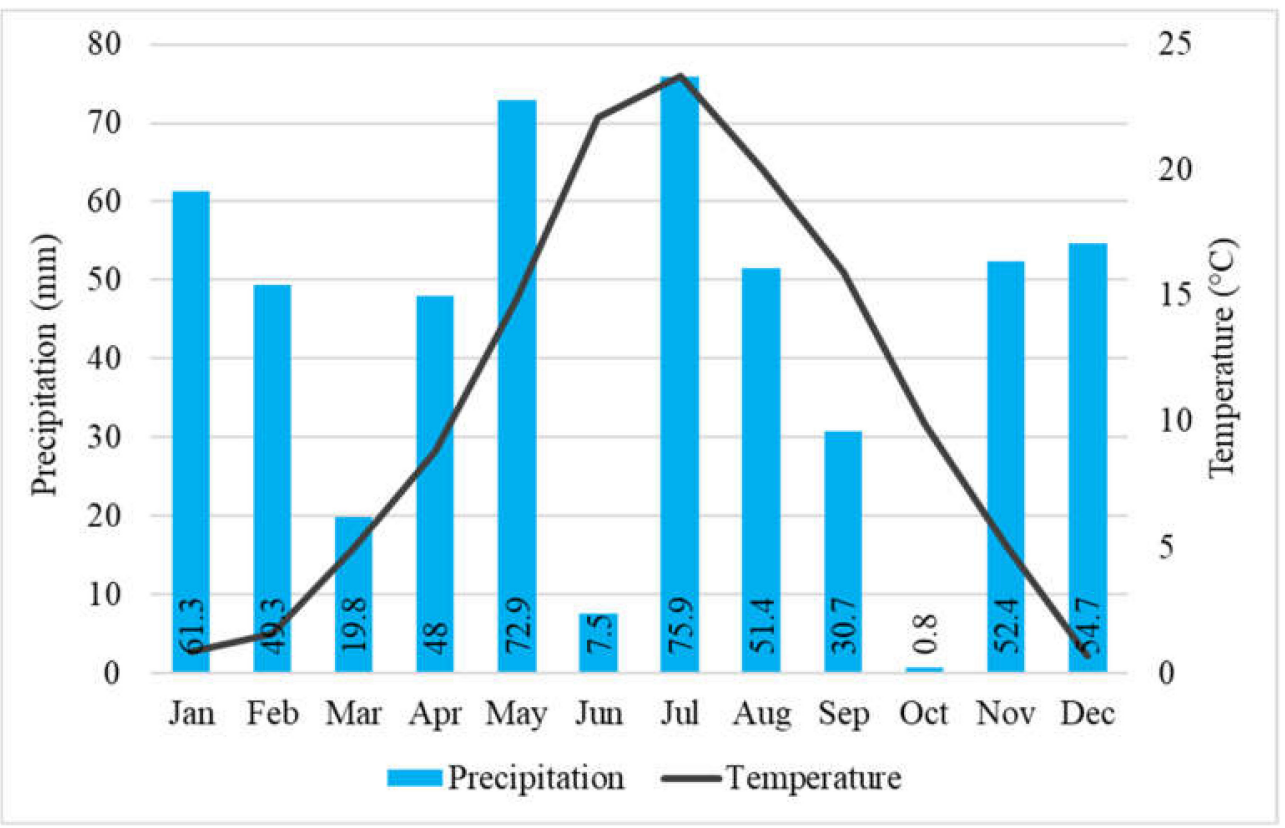

Figure 1. Monthly sums of precipitation and averages of temperature (Napkor, 2021). Numbers in the bars: sum precipitation of the month.

\subsection{Results of Assimilation Measurements}

Assimilation and water management studies in field experiments outside the laboratory are essential for understanding the assimilation processes of black locust. Measurements and studies related to photosynthesis processes have been carried out by many researchers in the laboratory on different crops, but relatively few publications have been published on the results of in situ measurements under field conditions. Assimilation parameters were measured on 29 June 2021, because the rate of net assimilation is the highest in this month [70]. There were significant differences $(p<0.001)$ in the assimilation rate of the clones (Figure 3a). The highest rate $\left(18.44 \mu \mathrm{mol} \mathrm{m}^{-2} \mathrm{~s}^{-1}\right)$ was in the 'NK2', the lowest $\left(9.62 \mu \mathrm{mol} \mathrm{m}{ }^{-2} \mathrm{~s}^{-1}\right)$ in the 'NK1' clone was observed. In the pairwise com- 
parison, the clones 'PL251' and 'PL040' did not differ significantly, the values were 13.34 and $12.96 \mu \mathrm{mol} \mathrm{m}{ }^{-2} \mathrm{~s}^{-1}$, respectively. The transpiration values also showed significant differences among the clones $(p<0.001)$. Besides the highest photosynthesis rate, the 'NK2' clone had the highest transpiration (6.53 $\mathrm{mmol} \mathrm{m}^{-2} \mathrm{~s}^{-1}$ ) (Figure 3b). In the 'Üllöi' variety was observed the second highest value both in the photosynthesis rate and in the transpiration, $15.17 \mu \mathrm{mol} \mathrm{m}^{-2} \mathrm{~s}^{-1}$, and $5.98 \mathrm{mmol} \mathrm{m}^{-2} \mathrm{~s}^{-1}$, respectively.

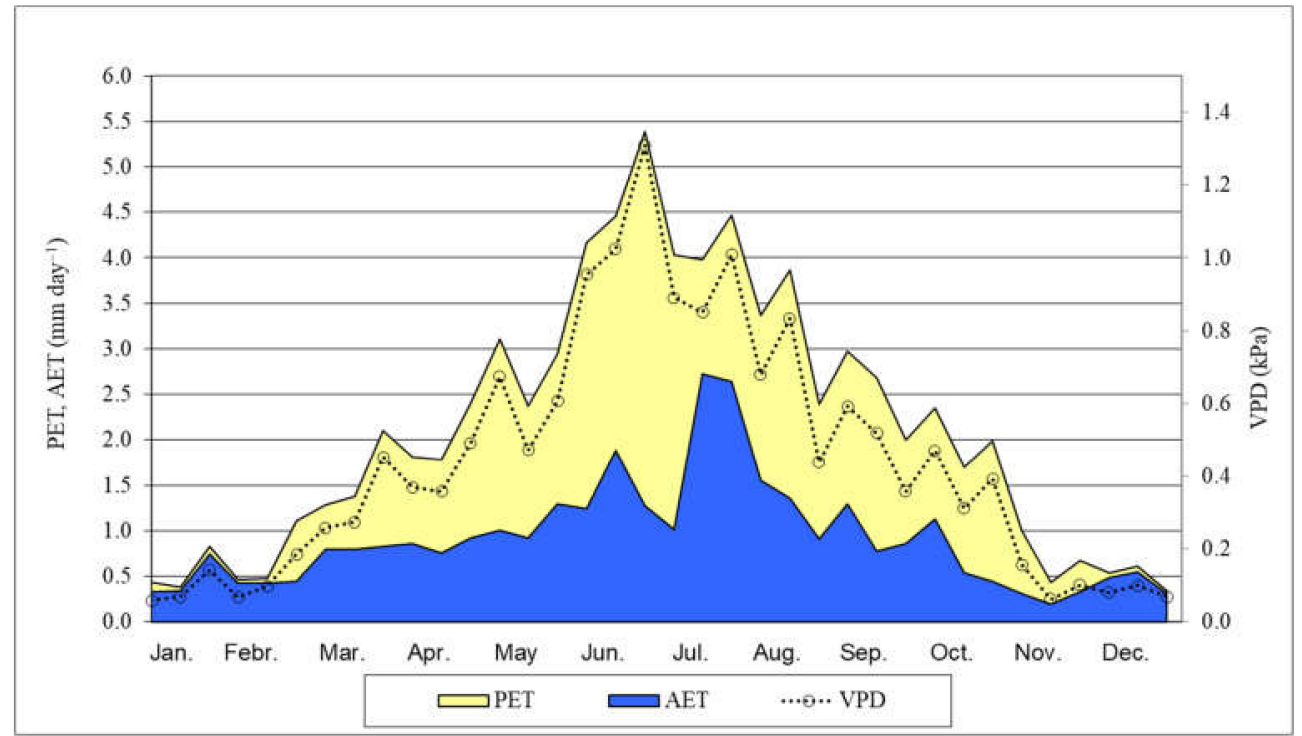

Figure 2. Potential (PET) and actual (AET) evapotranspiration, AET/PET ratio (\%) and VPD in black locust (Napkor, 2021). Average of the decades. VPD: Vapor pressure deficit, calculated using meteorological data.

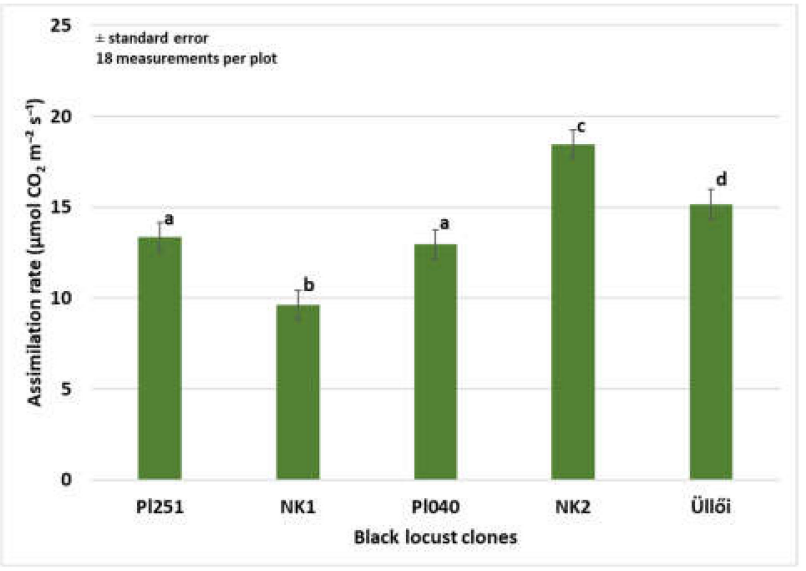

(a)

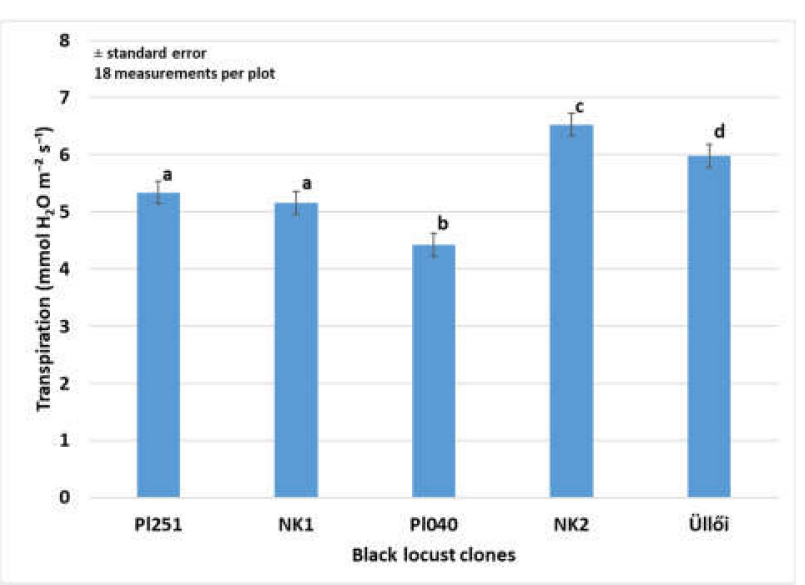

(b)

Figure 3. (a) Assimilation rate of black locust clones (29 May 2021) (b) Transpiration of black locust clones (2021); \pm standard error; The different letters mean significant difference at $p=0.05$ among the clones.

Using the assimilation rate and the transpiration data the water use efficiency (WUE) ( $\mathrm{kg} \mathrm{CO} 2$ per $\mathrm{m}^{3} \mathrm{H}_{2} \mathrm{O}$ ) was calculated for every clone (Table 1). The differences were significant at $p<0.001$ level. The best water use efficiency was observed in the 'PL040' clone $\left(7.015 \mathrm{~kg} \mathrm{~m}^{-3}\right)$, while the lowest value was in the ' $\mathrm{NK} 1$ ' clone $\left(4.319 \mathrm{~kg} \mathrm{~m}^{-3}\right)$. 
Table 1. Water use efficiency of the black locust clones (29 June 2021).

\begin{tabular}{cccccc}
\hline & \multicolumn{5}{c}{ Clones } \\
\cline { 2 - 6 } & PL251 & NK1 & PL040 & NK2 & Ü110́i \\
\hline $\begin{array}{c}\text { WUE } \\
\left(\mathrm{kg} \mathrm{m}^{-3}\right)\end{array}$ & $6.13 \pm 0.191 \mathrm{a}$ & $4.319 \pm 0.191 \mathrm{~b}$ & $7.015 \pm 0.191 \mathrm{c}$ & $6.876 \pm 0.191 \mathrm{c}$ & $6.207 \pm 0.191 \mathrm{a}$ \\
\hline
\end{tabular}

The different letters mean significant difference at $p=0.05$ among the clones.

Light response curves of one clone ('PL251') and the registered variety ('Üllói') were observed with decreasing photosynthetic photon flux density (PPFD) in 8 steps (Figure 4). There was significant difference $(p=0.05)$ in the assimilation rate between the variety and the clone at all PPFD levels, and the difference was higher at the higher photon flux densities. The natural logarithmic regression functions fit well to the measured data points $\left(R^{2}: 0.9444-0.9745\right)$, so the curves of the functions showed clearly the differences. At the low PPFD levels, from 0 to $300 \mu \mathrm{mol} \mathrm{m}{ }^{-2} \mathrm{~s}^{-1}$ the 'Üllöi' variety had higher assimilation rate, but as the light intensity increased, the 'PL251' clone had higher photosynthesis rate, the curve of 'Ülloi' ran lower than that of the other at higher than $300 \mu \mathrm{mol} \mathrm{m}{ }^{-2} \mathrm{~s}^{-1}$ photon flux density level. The assimilation rate of the clone 'PL251' increased to the $1500 \mu \mathrm{mol} \mathrm{m}{ }^{-2} \mathrm{~s}^{-1}$ PPFD level. In 'Üllói' variety the assimilation rate decreased above $1200 \mu \mathrm{mol} \mathrm{m}^{-2} \mathrm{~s}^{-1}$ PPFD.

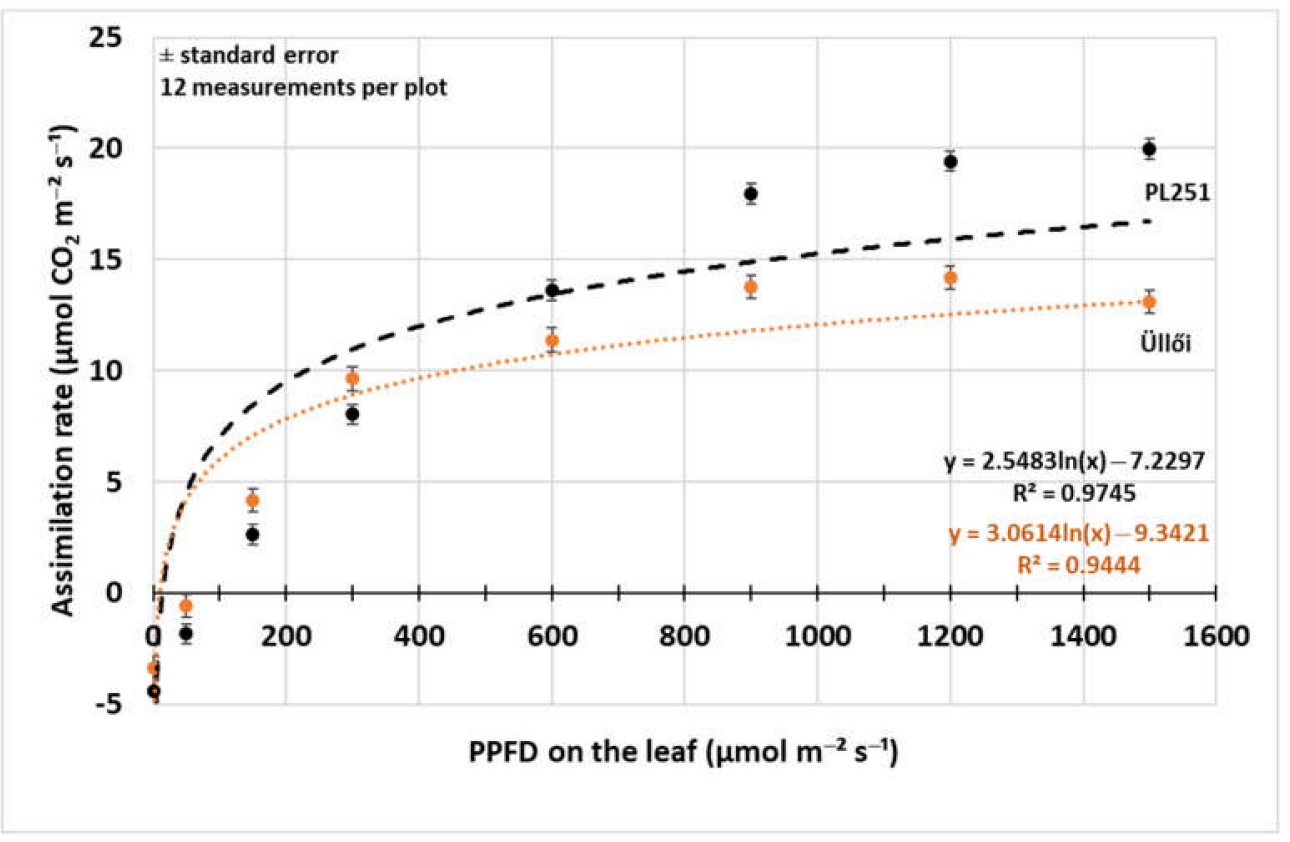

Figure 4. Photosynthesis rate light response curve of black locust clone 'PL251' and variety 'Üllöi' (29 May 2021); \pm standard error.

The tested black locust clones were classified using discriminant analysis. The grouping variable was the clone and, after standardization, the group of scale variables (assimilation rate, intercellular $\mathrm{CO}_{2}$ level, transpiration, total conductance to $\mathrm{CO}_{2}$, WUE, NDVI1-5, height) was used. Table 2 shows the discriminant analysis result. The classification was successful, $86.7 \%$ of original grouped cases were correctly classified. In 'PL251', 'NK1' and 'P1040' clones, all of the cases (100\%) were correctly classified. In 'NK2' and 'Üllói', the correctly classified cases were $66.7 \%$. The clones 'PL251' 'NK1', and 'PL040' are clearly separated on the combined groups plot (Figure 5), but overlapping can be observed in ‘NK2' and 'Üllöi'. 
Table 2. Discriminant analysis classification results, black locust clones.

\begin{tabular}{cccccc}
\hline \multirow{2}{*}{ Clones } & \multicolumn{5}{c}{ Predicted Group Membership } \\
\cline { 2 - 6 } & PL251 & NK1 & PL040 & NK2 & Üllói \\
\hline PL251 & $100 \%$ & $0 \%$ & $0 \%$ & $0 \%$ & $0 \%$ \\
NK1 & $0 \%$ & $100 \%$ & $0 \%$ & $0 \%$ & $0 \%$ \\
PL040 & $0 \%$ & $0 \%$ & $100 \%$ & $0 \%$ & $0 \%$ \\
NK2 & $0 \%$ & $0 \%$ & $0 \%$ & $66.7 \%$ & $33.3 \%$ \\
Üllői & $0 \%$ & $0 \%$ & $0 \%$ & $33.3 \%$ & $66.7 \%$ \\
\hline
\end{tabular}

$86.7 \%$ of original grouped cases correctly classified.

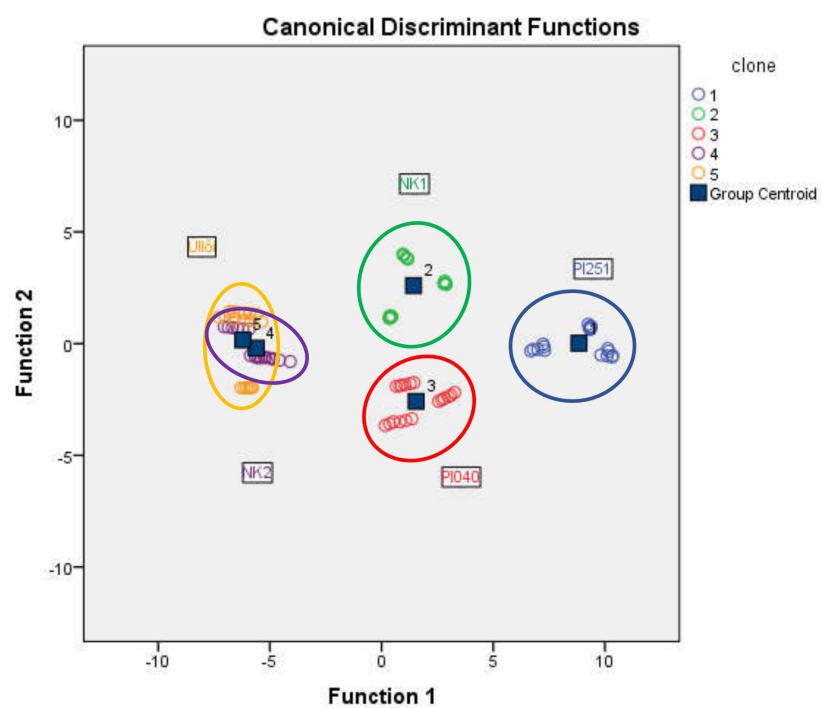

Figure 5. Combined group plot of the discriminant analysis of the black locust clones (Napkor, 2021).

\subsection{Results of Stand Structure Factors and Growth}

The results of the spring (May 2021) and autumn (November 2021) full inventories, the data on height, diameter at the base, and their increment are summarized in Table 3. Furthermore, Figure $6 \mathrm{a}, \mathrm{b}$ shows the difference between full inventories.

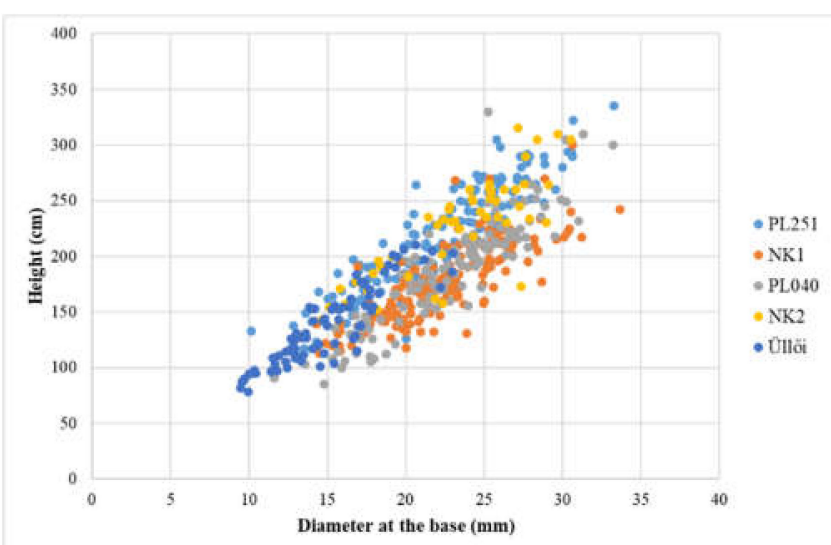

(a)

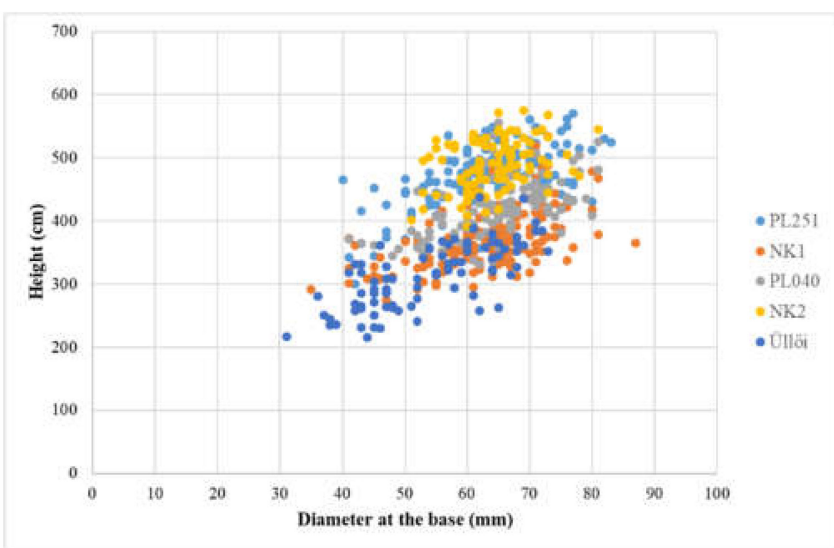

(b)

Figure 6. Comparison of results of full inventories: (a) May 2021; (b) November 2021. 
Table 3. Summary of the data from full inventories (May 2021 and November 2021).

\begin{tabular}{|c|c|c|c|c|c|c|c|}
\hline Clones & & & $\begin{array}{l}\text { Number } \\
\text { of Stems }\end{array}$ & $\begin{array}{l}\text { Height } \\
\text { (cm) }\end{array}$ & $\begin{array}{c}\text { Height } \\
\text { Increment }(\mathrm{cm})\end{array}$ & $\begin{array}{c}\text { Diameter at } \\
\text { the Base }(\mathrm{mm})\end{array}$ & $\begin{array}{l}\text { Diameter at the Base } \\
\text { Increment (mm) }\end{array}$ \\
\hline \multirow{2}{*}{ PL251 } & May & n1 & 137 & $219.1 \pm 4.139 \mathrm{a}$ & \multirow{2}{*}{255.1} & $22.08 \pm 0.395 \mathrm{a}$ & \multirow{2}{*}{40.9} \\
\hline & Nov. & $\mathrm{n} 2$ & 146 & $474.2 \pm 4.012 \mathrm{~A}$ & & $62.95 \pm 0.743 \mathrm{~A}$ & \\
\hline \multirow{2}{*}{ NK1 } & May & n1 & 157 & $177.0 \pm 2.795 b$ & \multirow{2}{*}{193.7} & $22.36 \pm 0.305 \mathrm{ab}$ & \multirow{2}{*}{40.8} \\
\hline & Nov. & $\mathrm{n} 2$ & 174 & $370.7 \pm 3.332 \mathrm{~B}$ & & $63.17 \pm 0.648 \mathrm{~A}$ & \\
\hline \multirow{2}{*}{ PL040 } & May & $\mathrm{n} 1$ & 124 & $188.7 \pm 4.326 \mathrm{c}$ & \multirow{2}{*}{236.1} & $22.87 \pm 0.379 \mathrm{ab}$ & \multirow{2}{*}{42.4} \\
\hline & Nov. & $\mathrm{n} 2$ & 126 & $424.9 \pm 3.966 \mathrm{C}$ & & $65.29 \pm 0.699 \mathrm{~B}$ & \\
\hline \multirow{2}{*}{ NK2 } & May & n1 & 50 & $227.8 \pm 6.273 \mathrm{a}$ & \multirow{2}{*}{261.2} & $23.44 \pm 0.583 \mathrm{~b}$ & \multirow{2}{*}{40.9} \\
\hline & Nov. & $\mathrm{n} 2$ & 97 & $489.0 \pm 4.091 \mathrm{D}$ & & $64.30 \pm 0.588 \mathrm{AB}$ & \\
\hline \multirow[b]{2}{*}{ Üllői } & May & n1 & 81 & $137.5 \pm 3.859 \mathrm{~d}$ & \multirow[b]{2}{*}{176.2} & $15.01 \pm 0.368 c$ & \multirow{2}{*}{38.9} \\
\hline & Nov. & n2 & 84 & $313.7 \pm 5.537 \mathrm{E}$ & & $53.92 \pm 1.108 \mathrm{C}$ & \\
\hline
\end{tabular}

Note: Nov. means November 2021. Sign "n1" indicates the number of the stems from full inventory in May 2021 and sign "n2" indicates the number of stems from full inventory in November 2021, n1 $\neq \mathrm{n} 2$. \pm standard error. Small letters indicate the significant difference $(p=0.05)$ between the clones from full inventory in May 2021 and capital letters indicate the significant difference $(p=0.05)$ between the clones from full inventory in November 2022.

In the evaluation of the results of the full inventory, carried out in May 2021, significant differences $(p=0.05)$ were observed between the clones tested for both height and diameter at the base. The best clones in terms of height were 'NK2' and 'PL251' and 'NK2', 'NK1' and 'PL040' in diameter at the base proved the most satisfactory. The performance of 'Üllöi' was the weakest for both examined parameters. The results of the November 2021 full inventory were almost similar to those of spring (May 2021). The clone 'NK2' was significantly the best in height and the 'PL040' clone was better than the 'NK2' clone with a minimal difference in diameter at the base (there was no significant difference between the two clones) and performed significantly better than the other clones (Table 3).

The height increase pattern of the clones and their comparison are shown in Figure 7. It shows that clones 'NK2' and 'PL251' performed best in terms of height increase during the studied period (from May 2021 to November 2021). The clones grew by $263 \mathrm{~cm}$ and $254 \mathrm{~cm}$, respectively, between May and November in 2021. The weakest growth was produced by 'Üllói' and 'NK1', with height increases of $188 \mathrm{~cm}$ and $212.5 \mathrm{~cm}$, respectively.

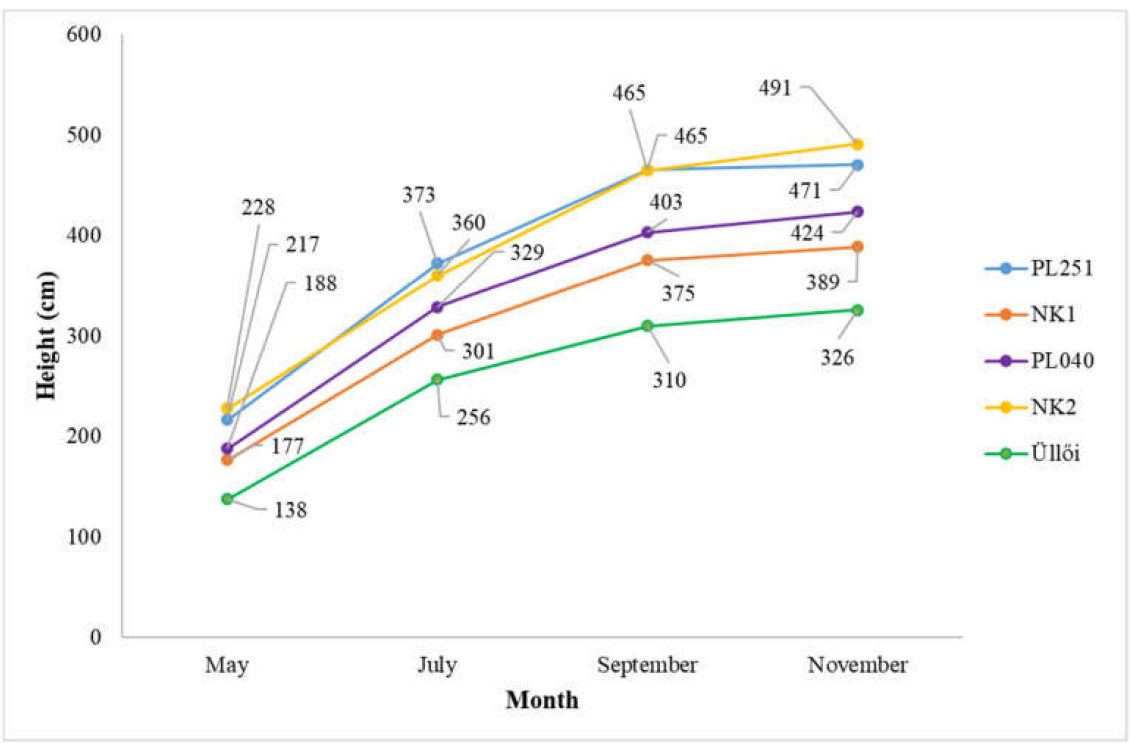

Figure 7. Height growth of the clones (May-November 2021). 


\subsection{Evaluation of the Results of Normalized Difference Vegetation Index (NDVI)}

The change in the normalized difference vegetation index (NDVI) values of the clones over the May-September period is shown in Figure 8.

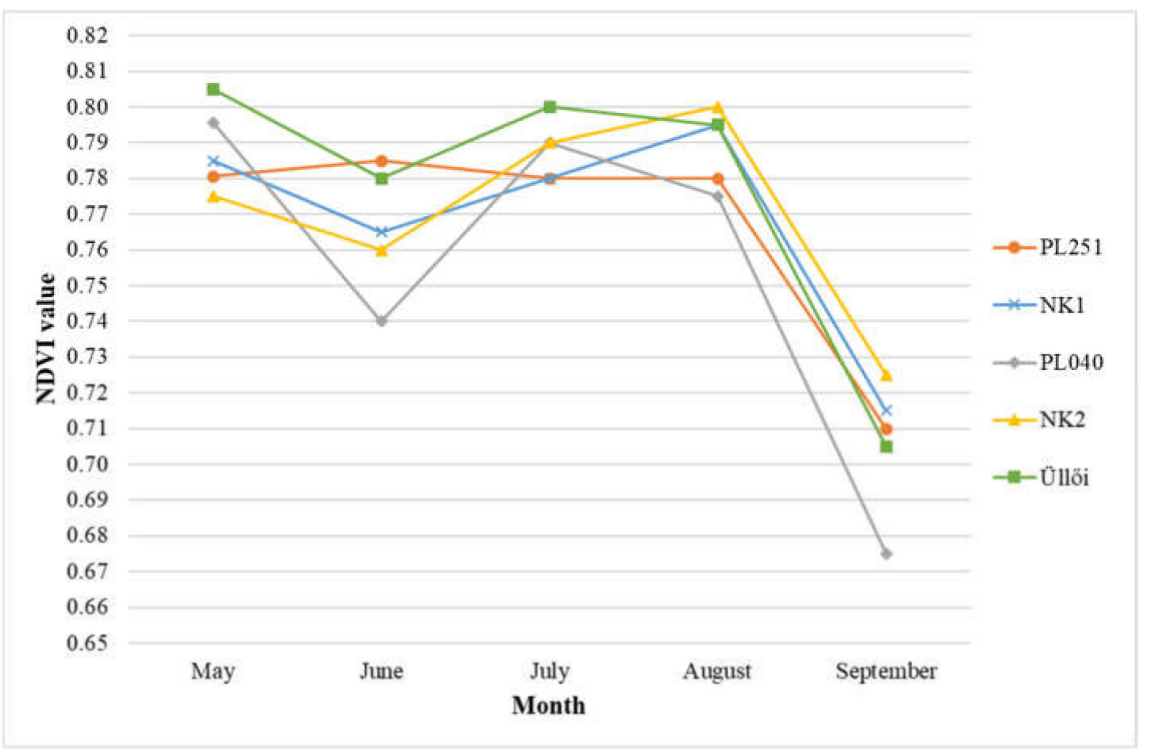

Figure 8. Normalized difference vegetation index (NDVI) values of black locust clones in the MaySeptember period in 2021.

Based on the results of the measurement in May, there was no significant difference between the clones. The NDVI values of the clones 'Üllöi' and 'PL040' (0.81 and 0.80, respectively) were higher than the other clones with a minimal difference. In June, 'PL251' and 'Üllöi' showed the best results ( 0.79 and 0.78 , respectively), the value in 'PL040' decreased (0.74), and proved to be significantly the weakest of this month. There was no significant difference between the NDVI values of the other clones. In July, the NDVI value of 'Üllö $\mathrm{i}^{\prime}$ (0.80) was the highest. There was a significant difference between 'Üllöi' and 'PL251' and 'NK1' clones. In August, 'NK2' produced the best value (0.80), significantly exceeding clones 'PL040' and 'PL251'. In September, the NDVI values of all clones decreased significantly (ranging from 0.67 to 0.73 ), probably due to the high degree of Parectopa robiniella infection. In this last month, the clone 'NK2' showed the best NDVI values (0.73) but differed significantly only from the clone 'PL040' with the lowest values (0.67).

Overall, clones 'Üllöi' and 'NK2' were the best in terms of the parameter (NDVI) investigated. The clone 'PL040' proved to be the weakest.

\section{Discussion}

The investigation of industrial tree plantations is of great practical importance. For 2020-2030, a massive shortage of timber can be forecasted in Hungary. The area of our hybrid poplar plantations is gradually decreasing. As black locust can tolerate even less favourable site conditions, the lack of timber can be reduced in the future by establishing black locust industrial tree plantations.

To be able to produce good quality industrial wood on the plantations, it is essential to study the phytophysiological properties of the trees (biomass production, vegetation activity of plants, chlorophyll content, photosynthetic activity) in addition to the traditional stand full inventories. Many literature sources are showing that significant differences in photosynthetic activity and transpiration can be found between the varieties in many field crops and trees, and the cultivars differed significantly also in the response to the different PPFD light intensities [71-75]. Our observations on the assimilation and water use properties provide new data for a better understanding of black locust timber formation processes. The assimilation rate of the clones increased with the increasing light intensity 
up to $1500 \mu \mathrm{mol} \mathrm{m} \mathrm{m}^{-2} \mathrm{~s}^{-1}$ PPFD level. The measured photosynthesis parameters showed significant differences among the black locust clones and based on the light response curve the clones also could be differentiated clearly. 'NK2' clone showed the highest assimilation rate and it had the highest height increment in the growing season, from May 2021 to November 2021.

Discriminant analysis is a good tool in the investigation of the relationship between the categorical, grouping variables and a group of scale variables. Some reports stated that the accuracy of the classification was affected by the phenological stages. The accuracy of the discrimination varied from 73 to $100 \%$, depending of the species and the growth stage [76,77]. In our study, the result of the discriminant analysis based on the observed parameters of the black locust clones showed that classification was successful, and $86.7 \%$ of original grouped cases were correctly classified. The accuracy varied from $66.7 \%$ to $100 \%$. The 'NK2' and 'Üllöi' showed differences in some parameters, but the separation was not clear.

Water use efficiency (WUE) is a useful parameter to characterize the water consumption and water supply state of a plant. The prolonged drought stress altered the morphological, physiological, and biochemical traits, but the responses could be species-specific but are also influenced by the characteristics of the cultivar [12,77]. To develop more efficient and precise measures, it is important to look for new insights concerning response mechanisms to drought stress. The deleterious effects caused by drought (e.g., water status and photosynthetic performance impairment, oxidative stress, and imbalance in plant nutrition), are the most critical stressors [78,79]. We also found significant differences in WUE among the black locust clones in our study. The means varied from 4.319 to $7.015 \mathrm{~kg} \mathrm{~m}^{-3}$, but the standard deviation was low, so the difference was significant at $p<0.001$ level.

The main growing period of black locust is from May to August [2,24]. According to Nadal-Sala et al. [80] the increasing temperature will extend the vegetative period of black locust, leading to significantly increased yield if the groundwater table keeps reachable. Our investigations have shown similar results. The clone with the best height growth, 'NK2', produced $10 \%$ of its height increment between September and November, despite the fact, that during the growing season droughty periods occurred, which caused water shortage problems on the sandy soil. Similar to the results of Theofanous et al. [81], the maximum values of height increments for the clones studied coincided with the NDVI values.

The NDVI values of the clones tested reached their maximum in May, but a secondary maximum was observed in August. This finding is partly supported by the report of Theofanous et al. [81], who found the maximum NDVI values of black locust in May-June.

Due to its flexible site tolerance, black locust is one of the most suitable fast-growing stand-forming tree species in reducing the unfavourable effects of global and local climate change. The invasive nature of black locust can be significantly reduced by developing and applying appropriate growing technology. In this field, the Hungarian research and development and innovation ( $R$ \& D \& I) results are also outstanding at the international level. Propagation of selected black locust varieties is only possible vegetatively in order to preserve the genetic surplus. Consequently, the large-scale, vegetative propagation of black locust clones (varieties) selected for relative drought tolerance and stem quality improvement must be resolved.

It should be noted that in terms of the international literature on black locust, there are relatively few field clone experiments established and evaluated with scientific demandingness. References to these should be treated with caution, as in most cases there is a lack of e.g., the origin of the propagating material, the technology of its production, the agronomic techniques used, etc.

The physiological studies presented in this paper are novel in the Hungarian forestry research and black locust growing research. We consider it important to carry out such studies in order to be able to produce the best possible wood quality in the future 


\section{Conclusions}

Plantation forestry, and within this, industrial tree plantations are primarily aimed at meeting the growing demand for wood material. In addition, they contribute to the development of the environment and the landscape, to the beneficial regulation of the atmospheric carbon cycle, to the filtering of various air pollutants, and, at the same time, to the mitigation of the harmful effects of climate change. Black locust can tolerate less favourable site conditions for tree growing. To be able to produce good quality black locust industrial wood raw material on plantations, it is essential to carry out the physiological studies described in our paper.

We can conclude that both of our hypotheses have been confirmed. There were significant differences among the clones in the growth and the plant physiology traits. Furthermore, the classification of the clones was successful based on the measured data.

The selected black locust varieties have and will play an important role in the following places of use, mainly in order to improve the quality of primary wood production:

- $\quad$ as a specified mixture (30-35\%) for the planting of common black locust stands,

- $\quad$ for the establishment of wide-spacing (min. $2.5 \times 2.0 \mathrm{~m}$ ), short-cutting (15-20 years) industrial tree plantations,

- $\quad$ for the establishment of seed-orchard and plantations for the production of quality propagating material.

Full knowledge of the ecological conditions, the introduction of modern new varieties into public cultivation, the development and introduction of new growing technologies, and the ecological, economic and physiological study of the entire growing cycle can form the basis for the full exploitation of the potential of plantations. This requires further innovation cooperation between research workshops and practitioners.

Author Contributions: Conceptualization, T.Á. and J.C.; methodology, Z.K.; software, J.C. and T.Á; validation, T.Á., Z.K. and J.C.; formal analysis, T.Á.; investigation, J.C. and Z.K and T.Á.; resources, T.Á. and Z.K. and J.C. and A.B.; data curation, T.Á.; writing-original draft preparation, Z.K. and J.C.; writing-review and editing, T.Á. and K.R.; visualization, T.Á. and J.C.; supervision, A.B. and K.R.; project administration, Z.K.; funding acquisition, T.Á. All authors have read and agreed to the published version of the manuscript.

Funding: This research was partially funded by "Project no. TKP2021-NKTA-43. It has been implemented with the support provided by the Ministry of Innovation and Technology of Hungary from the National Research, Development and Innovation Fund, financed under the TKP2021-NKTA funding scheme".

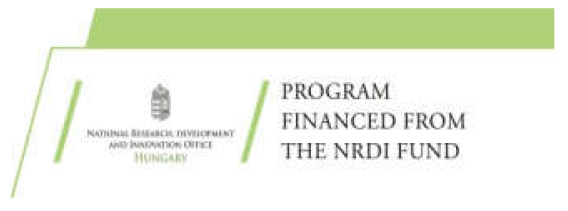

On the other hand this research was prepared with the professional support of the Doctoral Student Scholarship Program of the Co-operative Doctoral Program of the Ministry of Innovation and Technology financed from the National Research, Development and Innovation Fund (Scholarship contract ID: RH/527-1/2021).

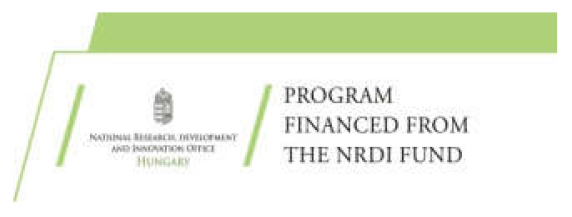

Institutional Review Board Statement: Not applicable. 
Informed Consent Statement: Not applicable.

Data Availability Statement: Not applicable.

Acknowledgments: The authors would like to thank Miklós Támba, for allowing and contributing to carrying out the tests in the area of the black locust plantation of Exclusive Stock Company of Napkori Foresters.

Conflicts of Interest: The authors declare no conflict of interest.

\section{References}

1. Vítková, M.; Müllerová, J.; Sádlo, J.; Pergl, J.; Pyšek, P. Black locust (Robinia pseudoacacia) beloved and despised: A story of an invasive tree in Central Europe. For. Ecol. Manag. 2017, 384, 287-302. [CrossRef] [PubMed]

2. Nicolescu, V.N.; Rédei, K.; Mason, W.L.; Vor, T.; Pöetzelsberger, E.; Bastien, J.C.; Brus, R.; Benčat', T.; Đodan, M.; Cvjetkovic, B.; et al. Ecology, growth and management of black locust (Robinia pseudoacacia L.), a non-native species integrated into European forests. J. For. Res. 2020, 31, 1081-1101. [CrossRef]

3. Huntley, J.C. Robinia pseudoacacia L. black locust. Silv. N. Am. 1990, 2, 755-761.

4. Barrett, R.P.; Mebrahtu, T.; Hanover, J.W. Black locust: A multi-purpose tree species for temperate climates. Advances in New Crops; Timber Press: Portland, OR, USA, 1990; pp. 278-283.

5. Noh, N.J.; Son, Y.; Koo, J.W.; Seo, K.W.; Kim, R.H.; Lee, Y.Y.; Yoo, K.S. Comparison of nitrogen fixation for north-and south-facing Robinia pseudoacacia stands in central Korea. J. Plant Biol. 2010, 53, 61-69. [CrossRef]

6. Böhm, C.; Quinkenstein, A.; Freese, D. Yield prediction of young black locust (Robinia pseudoacacia L.) plantations for woody biomass production using allometric relations. Ann. For. Res. 2011, 54, 215-227.

7. Wojda, T.; Klisz, M.; Jastrzebowski, S.; Mionskowski, M.; Szyp-Borowska, I.; Szczygiel, K. The geographical distribution of the black locust (Robinia pseudoacacia L.) in Poland and its role on non-forest land. Pap. Glob. Change 2015, 22. [CrossRef]

8. Qin, J.; Xi, W.; Rahmlow, A.; Kong, H.; Zhang, Z.; Shangguan, Z. Effects of forest plantation types on leaf traits of Ulmus pumila and Robinia pseudoacacia on the Loess Plateau, China. Ecol. Eng. 2016, 97, 416-425. [CrossRef]

9. Li, G.; Zhang, X.; Huang, J.; Wen, Z.; Du, S. Afforestation and climatic niche dynamics of black locust (Robinia pseudoacacia). For Ecol. Manag. 2018, 407, 184-190. [CrossRef]

10. Lee, H.; Lim, H.; Kang, J.W. Growth performance of exotic trees in Korea. J. For. Environ. Sci. 2019, 35, 115-120. [CrossRef]

11. Zhu, Y.; Wang, Y.; Chen, L.; Li, Z. Does non-native black locust afforestation affect soil biodiversity at the regional scale? Case study of soil macroinvertebrates across the Chinese Loess Plateau. Catena 2021, 200, 105171. [CrossRef]

12. Mantovani, D.; Veste, M.; Freese, D. Black locust (Robinia pseudoacacia L.) ecophysiological and morphological adaptations to drought and their consequence on biomass production and water-use efficiency. N. Z. J. For. Sci. 2014, 44, 1-11. [CrossRef]

13. Moser, A.; Rötzer, T.; Pauleit, S.; Pretzsch, H. The urban environment can modify drought stress of small-leaved lime (Tilia cordata Mill.) and black locust (Robinia pseudoacacia L.). Forests 2016, 7, 71. [CrossRef]

14. Moser, A.; Uhl, E.; Rotzer, T.; Biber, P.; Caldentey, J.M.; Pretzsch, H. Effects of climate and drought events on urban tree growth in Santiago de Chile. Cienc Invest Agrar 2018, 45, 35-50. [CrossRef]

15. Bhusal, N.; Lee, M.; Han, A.R.; Han, A.; Kim, H.S. Responses to drought stress in Prunus sargentii and Larix kaempferi seedlings using morphological and physiological parameters. For. Ecol. Manag. 2020, 465, 118099. [CrossRef]

16. Deng, L.; Shangguan, Z.P.; Rui, L.I. Effects of the grain-for-green program on soil erosion in China. Int. J. Sediment Res. 2012, 27, 120-127. [CrossRef]

17. Lee, C.S.; Cho, H.J.; Yi, H. Stand dynamics of introduced black locust (Robinia pseudoacacia L.) plantation under different disturbance regimes in Korea. For. Ecol. Manag. 2004, 189, 281-293. [CrossRef]

18. Zeleznik, J.D.; Skousen, J.G. Survival of three tree species on old reclaimed surface mines in Ohio. Am. Soc. Agron. Crop Sci. Soc. Am. Soil Sci. Soc. Am. 1996, 25, 1429-1435. [CrossRef]

19. Filcheva, E.; Noustorova, M.; Gentcheva-Kostadinova, S.V.; Haigh, M.J. Organic accumulation and microbial action in surface coal-mine spoils, Pernik, Bulgaria. Ecol. Eng. 2000, 15, 1-15. [CrossRef]

20. DeGomez, T.; Wagner, M.R. Culture and use of black locust. HortTechnology 2001, 11, 279-288. [CrossRef]

21. Grünewald, H.; Böhm, C.; Quinkenstein, A.; Grundmann, P.; Eberts, J.; von Wühlisch, G. Robinia pseudoacacia L.: A lesser known tree species for biomass production. BioEnergy Res. 2009, 2, 123-133. [CrossRef]

22. Rédei, K.; Osvath-Bujtas, Z.; Veperdi, I. Black locust (Robinia pseudoacacia L.) improvement in Hungary: A review. Acta Silv. Et Lignaria Hung. 2008, 4, 127-132.

23. Manzone, M.; Bergante, S.; Facciotto, G. Energy and economic sustainability of woodchip production by black locust (Robinia pseudoacacia L.) plantations in Italy. Fuel 2015, 140, 555-560. [CrossRef]

24. Keresztesi, B. The Black Locust; Akadémiai Kiadó: Budapest, Hungary, 1988.

25. Lee, K.J.; Sohn, J.H.; Rédei, K.; Yun, H.Y. Selection of early and late flowering Robinia pseudoacacia from domesticated and introduced cultivars in Korea and prediction of flowering period by accumulated temperature. J. Korean For. Soc. 2007, 96, 170-177.

26. Nicolescu, V.N.; Hernea, C.; Bakti, B.; Keserû, Z.; Antal, B.; Rédei, K. Black locust (Robinia pseudoacacia L.) as a multi-purpose tree species in Hungary and Romania: A review. J. For. Res. 2018, 29, 1449-1463. [CrossRef] 
27. Kim, Y.K.; Kim, M.S.; Nam, J.I.; Song, J.H.; Kim, S.H. Analysis on floral nectar characteristics among the selected black locust (Robinia spp.) individuals. J. Apic. Res. 2021, 1-9. [CrossRef]

28. Vadas, J. Az ákácfa Monográfiája; Országos Erdészeti Egyesület: Budapest, Hungary, 1911; p. 236.

29. Muller, S. Robinia pseudoacacia L. Le robinier faux-acacia. In: Muller, S.(Coordinateur): Plantes invasives en France. Muséum national d'Histoire naturelle, Paris. Patrimoins Nat. 2004, 62, 92-93. (In French)

30. Demené, J.M.; Merzeau, D. Le robinier faux acacia, Historique et caractéristiques biologiques. Forêt-Entreprise 2007, 177, 10-12. (In French)

31. Halmágyi, L.; Keresztesi, B. A Méhlegelő; Akadémiai Kiadó: Budapest, Hungary, 1975. (In Hungarian)

32. Járó, Z.; Lengyel, G. Stand establishment. In the Black Locust; Keresztesi, B., Ed.; Akadémiai Kiadó: Budapest, Hungary, 1988; pp. 87-115.

33. Meyer-Münzer, B.; Grotehusmann, H.; Vor, T. Robinie (Robinia pseudoacacia L.). In Potenziale Und Risiken Eingeführter Baumarten: Baumartenportraits Mit Naturschutzfachlicher Bewertung; Vor, T., Spellmann, H., Bolte, A., Ammer, C., Eds.; Universitätsverlag Göttingen: Göttingen, Germany, 2015; pp. 277-296. (In German)

34. Vítková, M.; Tonika, J.; Müllerová, J. Black locust-Successful invader of a wide range of soil conditions. Sci. Total Environ. 2015, 505, 315-328. [CrossRef]

35. UN FAO. Global Forest Resources Assessment 2020 Report Hungary; UN FAO: Rome, Italy, 2020.

36. Rédei, K.; Csiha, I.; Keserú, Z.; Kamandiné Végh, Á.; Győri, J. The silviculture of black locust (Robinia pseudoacacia L.) in Hungary: A review. South-East Eur. For. SEEFOR 2011, 2, 101-107. [CrossRef]

37. Rédei, K.; Keserú, Z.; Csiha, I.; Rásó, J.; Honfy, V. Plantation silviculture of black locust (Robinia pseudoacacia L.) cultivars in Hungary-a review. South-East Eur. For. SEEFOR 2017, 8, 151-156. [CrossRef]

38. Rédei, K.M.; Keserú, Z.; Bach, I.; Rásó, J.; Ábri, T.; Gál, J. Management of Robinia pseudoacacia cv.'Üllői'-‘Üllői'locust. Acta Silv. Et Lignaria Hung. 2020, 16, 9-18. [CrossRef]

39. Ábri, T.; Keserü, Z.; Rásó, J.; Rédei, K. Stand structure and growth of Robinia pseudoacacia ‘Jászkiséri'-‘Jászkiséri'black locust. J. For. Sci. 2021, 67, 489-497. [CrossRef]

40. Rédei, K.; Keserû, Z.; Rásó, J. Early evaluation of micropropagated black locust (Robinia pseudoacacia L.) clones in Hungary. For. Sci. Pract. 2013, 15, 81-84. [CrossRef]

41. Rédei, K.; Keserú, Z.; Csiha, I.; Rásó, J.; Kamandiné Végh, Á.; Antal, B. Juvenile Growth and Morphological Traits of Micropropagated Black Locust (Robinia pseudoacacia L.) Clones under Arid Site Conditions. Acta Silv. Et Lignaria Hung. 2013, 9, 35-42. [CrossRef]

42. Keserû, Z.; Borovics, A.; Ábri, T.; Rédei, K.M.; Lee, I.H.; Lim, H. Growing of Black Locust (Robinia pseudoacacia L.) Candidate Cultivars on Arid Sandy Site. Acta Silv. Et Lignaria Hung. 2021, 17, 51-61. [CrossRef]

43. Keresztesi, B. Breeding and cultivation of black locust, Robinia pseudoacacia, in Hungary. For. Ecol. Manag. 1983, 6, 217-244. [CrossRef]

44. Rédei, K.; Ostváth-Bujtás, Z.; Balla, I. Propagation methods for black locust (Robinia pseudoacacia L.) improvement in Hungary. J. For. Res. 2001, 12, 215-219. [CrossRef]

45. Rédei, K.; Ostváth-Bujtás, Z.; Balla, I. Clonal approaches to growing black locust (Robinia pseudoacacia L.) in Hungary: A review. For. Int. J. For. Res 2002, 75, 547-552. [CrossRef]

46. Barghchi, M. Mass clonal propagation in vitro of Robinia pseudoacacia L.(black locust) cv.'Jaszkiseri'. Plant Sci. 1987, 53, 183-189. [CrossRef]

47. Hanover, J.W.; Mebrathu, T.; Bloese, P. Genetic improvement of black locust: A prime agroforestry species. For. Chron. 1991, 67, 227-231. [CrossRef]

48. Davis, J.M.; Keathley, D.E. Micropropagation of Black Locust (Robinia pseudoacacia L.). In High-Tech and Micropropagation II. Biotechnology in Agriculture and Forestry; Bajaj, Y.P.S., Ed.; Springer: Berlin/Heidelberg, Germany, 1992; Volume 18. [CrossRef]

49. Chalupa, V. Tissue culture propagation of black locust. In Biology, Culture and Utilization; Hanover, J.W., Miller, K., Plesko, S., Eds.; Michigan State University: East Lansing, MI, USA, 1992; pp. 115-125.

50. Chang, C.S.; Bongarten, B.; Hamrick, J. Genetic structure of natural populations of black locust (Robinia pseudoacacia L.) at Coweeta, North Carolina. J. Plant Res. 1998, 111, 17-24. [CrossRef]

51. Swamy, S.L.; Puri, S.; Kanwar, K. Propagation of Robinia pseudoacacia Linn. and Grewiaoptiva Drummond from rooted stem cuttings. Agrofor. Syst. 2002, 55, 231-237. [CrossRef]

52. Liesebach, H.; Yang, M.S.; Schneck, V. Genetic diversity and differentiation in a black locust (Robinia pseudoacacia L.) progeny test. For. Genet. 2004, 11, 151-161.

53. Zhang, J.; Liu, Y.; Wang, H. Micropropagation of black locust (Robinia pseudoacacia L.). Protoc. Micropropag. Woody Trees Fruits 2007, 19, 193-199. [CrossRef]

54. Dini-Papanastasi, O. Effects of clonal selection on biomass production and quality in Robinia pseudoacacia var. monophylla Carr. For. Ecol. Manag. 2008, 256, 849-854. [CrossRef]

55. Zhonghai, S. Research on the rapid propagation technology of tetraploid Robinia Pseudoacacia. J. Anhui Agric. Sci. $2008,36,2315$.

56. Dini-Papanastasi, O.; Kostopoulou, P.; Radoglou, K. Effects of seed origin, growing medium and mini-plug density on early growth and quality of black locust (Robinia pseudoacacia L.) seedlings. J. For. Sci. 20012, 58, 8-20. 
57. Lu, N.; Dai, L.; Wu, B.; Zhang, Y.; Luo, Z.; Xun, S.; Sun, Y.; Li, Y. A preliminary study on the crossability in Robinia pseudoacacia L. Euphytica 2015, 206, 555-566. [CrossRef]

58. Szyp-Borowska, I.; Banha, C.; Wojda, T.; Szczygieł, K. Micropropagation of black locust (Robinia pseudoacacia L.) and genetic stability of long term cultivated plants. Folia For. Pol. 2016, 58, 13-19. [CrossRef]

59. Han, C.; Xun, S.; Zhang, Y.; Qiao, Y.; Dong, Y.; Zhong, W.; Liu, Z.; Li, Q. A new cultivar of Robinia pseudoacacia'Lüman Qingshan'. Acta Hortic. Sin. 2019, 46, 1425-1426. [CrossRef]

60. Stankova, T.; Gyuleva, V.; Kalmukov, K.; Popov, E.; Pérez-Cruzado, C.; Glushkova, M.; Andonova, E. Effect of spacing, parental genotype and harvesting cycle on biomass production in two half-sib progenies of Robinia pseudoacacia L. For. Int. J. For. Res. 2020, 93, 505-518. [CrossRef]

61. Yang, X.; Zhang, K.; Wang, J.; Jia, H.; Ma, L.; Li, Y.; Duan, J. Assessment of genetic diversity and chemical composition among seven black locust populations from Northern China. Biochem. Syst. Ecol. 2020, 90, 104010. [CrossRef]

62. Kraszkiewicz, A. Productivity of Black Locust (Robinia pseudoacacia L.) Grown on a Varying Habitats in Southeastern Poland Forests 2021, 12, 470. [CrossRef]

63. Rouse, W.J.; Haas, R.H.; Schell, J.A.; Deering, D.W. Monitoring Vegetation Systems in the Great Plains with ERTS. In Proceedings of the Third ERTS Symposium, Washington, DC, USA, 10-14 December 1973; pp. 309-317.

64. Hungarian Meteorological Service. Available online: https://met.hu/omsz/tevekenysegek/adattar/ (accessed on 10 January 2022).

65. USS Working Group WRB. World Reference Base for Soil Resources 2014, International Soil Classification System for Naming Soils and Creating Legends for Soil Maps; World Soil Resources Reports: Rome, Italy, 2015.

66. LI-COR Inc. Li-6800 Portable Photosynthesis System, Software Version 1.2; LI-COR Inc.: Lincoln, NE, USA, 2017.

67. Tanner, C.B.; Sinclair, T.R. Efficient water use in crop production: Research or re-search. In Limitations to Efficient Water Use in Crop Production; ASA: Madison, WI, USA, 1983.

68. Allen, R.G.; Pereira, L.S.; Raes, D.; Smith, M. Crop Evapotranspiration-Guidelines for Computing Crop Water Requirements-FAO Irrigation and Drainage Paper 56; FAO-Food and Agriculture Organization of the United Nations: Rome, Italy, 1998.

69. Antal, E. Az éghajlatváltozás hatása a magyarországi aszályokra. Acta Geogr. Debrecina 1991, 28, 17-18. (In Hungarian)

70. Lyr, H.; Fiedler, H.J.; Tranquillini, W. Physiologie und ökologie der Gehölze; Gustav Fischer Verlag: Jena, Germany, 1992. (In German)

71. Kutasy, E.; Buday-Bódi, E.; Virág, I.C.; Forgács, F.; Melash, A.A.; Zsombik, L.; Nagy, A.; Csajbók, J. Mitigating the Negative Effect of Drought Stress in Oat (Avena sativa L.) with Silicon and Sulphur Foliar Fertilization. Plants 2022, 11, 30. [CrossRef] [PubMed]

72. Csajbók, J.; Pepó, P.; Kutasy, E. Photosynthetic and Agronomic Traits of Winter Barley (Hordeum vulgare L.) Varieties. Agronomy 2020, 10, 1999. [CrossRef]

73. Bhusal, N.; Bhusal, S.J.; Yoon, T.-M. Comparisons of physiological and anatomical characteristics between two cultivars in bi-leader apple trees (Malus $\times$ domestica Borkh. ) Sci. Hortic. 2018, 231, 73-81. [CrossRef]

74. Stavros, N.; Petri, V.E.; Stournaras, V. Seasonal changes in photosynthetic activity and carbohydrate content in leaves and fruit of three fig cultivars (Ficus carica L.). Sci. Hortic. 2013, 160, 198-207. [CrossRef]

75. Balla, K.; Bedo, Z.; Veisz, O. Effect of heat and drought stress on the photosynthetic processes of wheat. Cereal Res. Commun. 2006, 2006. 34, 381-384. [CrossRef]

76. Chivasa, W.; Mutanga, O.; Biradar, C. Phenology-based discrimination of maize (Zea mays L.) varieties using multitemporal hyperspectral data. J. Appl. Remote Sens. 2019, 13, 017504. [CrossRef]

77. Zhang, H.; Hinze, L.L.; Lan, Y.; Westbrook, J.K.; Hoffmann, W.C. Discriminating among Cotton Cultivars with Varying Leaf Characteristics Using Hyperspectral Radiometry. Trans. ASABE 2012, 55, 275-280. [CrossRef]

78. Bhusal, N.; Lee, M.; Lee, H.; Adhikari, A.; Han, A.R.; Han, A.; Kim, H.S. Evaluation of morphological, physiological, and biochemical traits for assessing drought resistance in eleven tree species. Sci Total Environ. 2021, 779, 146466. [CrossRef]

79. Cátia, B.; Dinis, L.-T.; Moutinho-Pereira, J.; Correia, C.M. Drought Stress Effects and Olive Tree Acclimation under a Changing Climate. Plants 2019, 8, 232. [CrossRef]

80. Nadal-Sala, D.; Hartig, F.; Gracia, C.A.; Sabaté, S. Global warming likely to enhance black locust (Robinia pseudoacacia L.) growth in a Mediterranean riparian forest. For. Ecol. Manag. 2019, 449, 117448. [CrossRef]

81. Theofanous, N.; Chrysafis, I.; Mallinis, G.; Domakinis, C.; Verde, N.; Siahalou, S. Aboveground Biomass Estimation in Short Rotation Forest Plantations in Northern Greece Using ESA's Sentinel Medium-High Resolution Multispectral and Radar Imaging Missions. Forests 2021, 12, 902. [CrossRef] 